\section{UDC: 316.012:141.7}

DOI: https://doi.org/10.32689/2617-

2224-2020-1(21)-27-41

\section{Афонін Едуард Андрійович,}

доктор сочіологічних наук, професор, професор кафедри публічної політики та політичної аналітики, Національна академія державного управління при Президентові України, 03057, м. Київ, вул. Антона Цедіка, 20, тел.: +38 (067) 24446 59, e-mail: bpafonin@gmail. com

ORCID: 0000-0002-7493-6907

\section{Афонин Эдуард Андреевич,}

доктор сочиологических наук, профессор, профессор кафедры публичной политики и политической аналитики, Начиональная академия государственного управления при Президенте Украины, 03057, 2. Киев, ул. Антона Цедика, 20, тел.: +38 (067) 24446 59, e-mail: bpafonin@gmail. com

\section{ORCID: 0000-0002-7493-6907}

\section{Afonin Eduard Andriyozych,}

Doctor of Sociological Sciences, Professor, Professor of the Chair of Public Policy and Political Analytics, National Academy of Public Administration under the President of Ukraine, 03057, Kyiv, Str. Antona Tsedika, 20, tel.: +38 (067) 24446 59, e-mail:bpafonin@gmail.com

$$
\text { ORCID: 0000-0002-7493-6907 }
$$

\section{Мартинов Андрій Юрійович,}

доктор історичних наук, професор, провідний науковий співробітник відділу історї міжнародних відносин $і$ зовнішньої політики України, Інститут історії України НАН України, 01001, м. Київ, вул. Грушевського, 4, тел.: +38 (044) 48315 72,e-mail: martynoz.andriy@ gmail.com

$$
\text { ORCID: 0000-0002-9802-5980 }
$$

\section{Мартынов Андрей Юрвевич,}

доктор исторических наук, профессор, ведущий научный сотрудник отдела истории международных отношений и внешней политики Украины, Институт истории
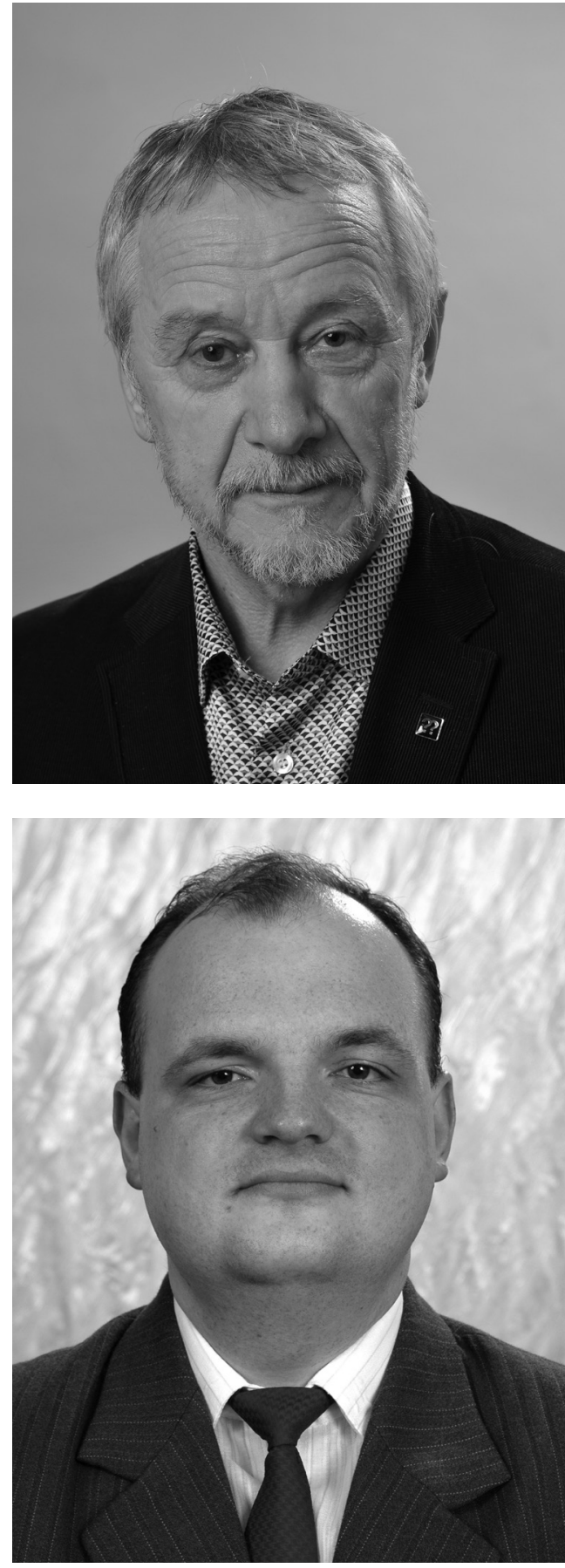
Украины НАН Украины, 01001, г. Киев, ул. Грушевского 4, тел.: +38 (044) 48315 72, e-mail:martynoz.andriy@gmail.com

ORCID: 0000-0002-9802-5980

Martynov Andrii Yuriyovych,

Doctor of Historical Sciences, Professor, Leading Researcher, Department of History of International Relations and Foreign Policy of Ukraine, Institute of History of Ukraine, National Academy of Sciences of Ukraine, 01001, Kyiv, Str. Hrushevskoho, 4, tel.: +38 (044) 48315 72,e-mail:martynov.andriy@gmail.com

ORCID: 0000-0002-9802-5980

\section{ТРАДИЦІЯ ЯК ФАКТОР ІНТЕГРАЦІї ТА КОНСОЛІДАЦІЇ УКРАЇНСЬКОГО СУСПІЛЬСТВА В УМОВАХ ПОСТМОДЕРНУ: АРХЕТИПНИЙ ПІДХІД}

Анотація. Розглядається феномен соціально-історичної традиції як чинник соціальної інтеграції та консолідації українського суспільства. Традиція визначається як процес відтворення через соціальні інститути досвіду поколінь та адаптація цього досвіду до вимог сучасності. Стверджується, що адаптація традиції до постмодерної сучасності є складним соціально-історичним і соціально-психологічним процесом, у контексті якого відбувається зміна світоглядної парадигми та виникає новий - раціональний тип мислення, що впливає на соціальні практики і соціальну поведінку. Налаштовуючи нащадки на інноваційну діяльність постмодерн розмиває великі нарративи традицій і заперечує соціальний досвід попередніх поколінь. Під впливом інновації суспільна система фрагментується і невпинно тяжіє до стану аномії. За цих обставин традиція, їі суб’єкти і носії стають конструктивним фактором соціальної консолідації, що відбувається в контексті вирішення актуальних питань інноваційного розвитку. Традиція і традиційна діяльність виступають своєрідними ціннісно-смисловими формами у вигляді нових міфів і міфотворчості, які протистоять втраті національної ідентичності і суспільної цілісності. Теоретичне підгрунтя такої діяльності, на думку авторів, представив французький соціолог Ж. Дюран, який запропонував концепцію імажинера як механізму конструювання соціальної реальності. Цей механізм, за думкою Ж. Дюрана, є одночасно уявою, уявленим та уявленням, а реальність - втіленням вільної гри уяви, на яку впливають міфи та архетипи. Імажинер існує у двох режимах: денному (діурн) та нічному (ноктюрн). Перший функціонує в дуальній формі, якій властиві ієрархічність і патріархальність, втілені у героїчному міфі. Натомість другий виявляється як цілісний містичний міф або смерть як інша реальність. На 
думку авторів, імажинер як втілення колективного несвідомого, пов'язаний 3 такими архетипними властивостями суспільної системи як екстернальність / інтернальність (зовнішній / внутрішній локус-контроль), екстраверсія / інтроверсія (соціальна / соцієтальна ідентичність), екзекутивність / інтенціональність (жіночі / чоловічі соціальні ролі). Відповідно минула суспільно-історична доба модерну пов’язана з функціонуванням режиму діурну, архетипами і міфотворчістю, які тісно пов’язані з реалізацією зовнішнього соціального контролю, патріархальності (соціальної ідентичності) та зростанням у суспільній системі кількості жіночих соціальних ролей. Постмодерна сучасність актуалізує режим ноктюрну, за умов якого в системі посилюється самоконтроль, розмивається ієрархічність та зростає кількість чоловічих соціальних ролей.

Ключові слова: архетип, ідентичність, імажінер, інновація, соціальна інтеграція, соціальний контроль, соціальні ролі, постмодерн.

\section{ТРАДИЦИЯ КАК ФАКТОР ИНТЕГРАЦИИ И КОНСОЛИДАЦИИ УКРАИНСКОГО ОБЩЕСТВА В УСЛОВИЯХ ПОСТМОДЕРНА: АРХЕТИПИЧЕСКИЙ ПОДХОД}

Аннотация. Рассматривается феномен социально-исторической традиции как фактор социальной интеграции и консолидации украинского общества. Традиция определяется как процесс воспроизводства через социальные институты опыта поколений и адаптации этого опыта к требованиям современности. Утверждается, что адаптация традиции к постмодерной современности является сложным социально-историческим и социальнопсихологическим процессом, в контексте которого происходит изменение мировоззренческой парадигмы и возникает новый - рациональный тип мышления, который влияет на социальные практики и социальное поведение. Настраивая потомки на инновационную деятельность постмодерн размывает большие нарративы традиций и отрицает социальный опыт предыдущих поколений. Под влиянием инновации общественная система фрагментируется и постоянно тяготеет к состоянию аномии. В этих условиях традиция, ее субъекты и носители становятся конструктивным фактором социальной консолидации, которая происходит в контексте решения актуальных вопросов инновационного развития. Традиция и традиционная деятельность выступают своеобразными ценностно-смысловыми формами в виде новых мифов и мифотворчества, которые противостоят потере национальной идентичности и общественной целостности. Теоретические основы такой деятельности, по мнению авторов, представил французский социолог Ж. Дюран, который предложил концепцию имажинера как механизма конструирования социальной реальности. Этот механизм, по мнению Ж. Дюрана, является первичным процессом, состоящим из воображаемого, воображающего, воображения и самого процесса воображения одновременно, а реальность - воплощением свободной игры воображения, на которую влияют мифы и архетипы. Имажинер существует в двух режимах: дневном 
(диурн) и ночном (ноктюрн). Первый работает в дуальной форме, которой присущи иерархичность и патриархальность, воплощенные в героическом мифе. А второй предстает как целостный мистический миф или смерть как другая реальность. По мнению авторов, имажинер, как воплощение коллективного бессознательного, связан с такими архетипическими свойствами общественной системы, как экстернальность / интернальность (внешний / внутренний локус-контроль), экстраверсия / интроверсия (социальная / социетальная идентичность), экзекутивность / интенциональность (женские / мужские социальные роли). При этом прошлая общественно-историческая эпоха модерна связана с функционированием режима диурна, архетипами и мифотворчеством, которое тесно связано с реализацией внешнего социального контроля, патриархальностью (социальной идентичностью) и ростом в общественной системе количества женских социальных ролей. Постмодернистская современность актуализирует режим ноктюрна, в условиях которого в системе усиливается самоконтроль, размывается иерархичность и растет количество мужских социальных ролей.

Ключевые слова: архетип, идентичность, имажинер, инновация, социальная интеграция, социальный контроль, социальные роли, постмодерн.

\section{TRADITION AS A FACTOR OF INTEGRATION AND CONSOLIDATION OF UKRAINIAN SOCIETY IN THE CONDITIONS OF POSTMODERN: ARCHETYPIC APPROACH}

Abstract. The article deals with the phenomenon of socio-historical tradition as a factor of the social integration and consolidation of the Ukrainian society. Tradition is defined as the process of reproducing, through social institutions, the experience of generations and the adaptation of this experience to the requirements of the present. It is argued that the adaptation of tradition to the postmodern modernity is a complex socio-historical and socio-psychological process, in the context of which a paradigm shift is taking place and a new - rational type of thinking influencing the social practices and social behaviour is emerging. By setting posterity to innovation, the postmodern blurs the great narratives of the tradition and denies the social experience of the previous generations. Under the influence of innovation, the social system is fragmented and constantly gravitates to the state of anomie. In these circumstances, tradition, its subjects and carriers become a constructive factor of the social consolidation, which takes place in the context of solving pressing issues of the innovative development. Tradition and traditional activity act as a kind of value-semantic forms in the form of new myths and myth-making, which counteract the loss of the national identity and social integrity. The theoretical basis of such activity, according to the authors, was presented by the French sociologist J. Durant, who proposed the concept of the imaginary as a mechanism for constructing the social reality. This mechanism, according to J. Durant, is both imagination, imaginary and imagined, and reality is the embodiment of a free play of the imagination, which is influenced by myths and archetypes. The imaginary exists in two modes: daytime (diurnal) and night 
(nocturne). The former functions in a dual form characterized by the hierarchy and patriarchy embodied in the heroic myth. Instead, the second is presented as a holistic mystical myth or death as another reality. According to the authors, the imaginary, as the embodiment of the collective unconscious, is associated with such archetypal properties of the social system as externality / internality (external / internal locus control), extraversion / introversion (social / social identity), executiveness / intentionality (female / male social roles). Accordingly, the past social and historical era of the modernity is connected with the functioning of the regime of the diurnal, archetypes and myth-making, which are closely linked to the realization of the external social control, patriarchy (social identity) and the growth in the social system of the number of women's social roles. The postmodern modernity actualizes the nocturnal regime under which conditions the system increases self-control, blurs hierarchy and increases the number of the male social roles.

Keywords: archetype, identity, imaginary, innovation, social integration, social control, social roles, postmodern.

Постановка проблеми. Складні й неоднозначні за змістом і спрямованістю сучасні тенденції розвитку науки найбільш рельєфно виявляють себе у гуманітарній сфері. Адже нинішні перехідні процеси розвитку людини, суспільства і людства в цілому не просто змінють характер діяльності людей, а й руйнуються їхні поведінкові стереотипи, розмивають ціннісні орієнтири та соціальні норми. 3 переходом до суспільства-постмодерну посилюється значення людської уяви як способу конструювання соціальної реальності, яка стає наслідком трансформаційних процесів в суспільстві і порушення причинно-наслідкових зв'язків, характерних колишньому об'єктивному науковому методу. Тотальна “суб'єктивація суспільного простору”породжує упередженість до таких компенсаторних можливостей людини, як традиційне знання та інтуїція. Реальний соціальний про- стір дедалі стає кібернетичним, а всі об’єкти навколо нас об’єднує “інтернет речей”, в якому зникають будьякі суттєві відмінності між онлайн- і офлайн-світом. Люди потребують нового визначення “здорового глузду”. Адже тепер ми перетворюємося на “світ гейміфікації”, в якому панують ігрові практики і механізми, що спираються на людські інстинкти. Становлення та розвиток штучного соціального простору - простору “інтернет речей”, який розмиває межі між матеріальною дійсністю і віртуальною реальністю. Загрозою людині стає штучний інтелект, який набуває більшої небезпеки, ніж ядерне озброєння. Історія цивілізації, образно кажучи, перетворюється на перегони між освітою та катастрофою.

Отже, дедалі людство просувається шляхом інновацій, тим очевиднішою стає наша безсилість вирішувати проблеми сучасності тим самим 
способом мислення, яким ми користувалися, у попередні часи.

Аналіз останніх досліджень i публікацій. Проблематика соціальної конфліктності, що супроводжує шлях до постмодерної сучасності, актуалізує дискурс навколо пошуку шляхів до консолідації та використання в цьому процесі потенціалу традицій. У Національній доповіді 2017 р. "Україна: шлях до консолідаціï”констатується, що “модель суспільної консолідації не може бути самонародженим феноменом. Потрібна стратегія 111 досягнення”. Авторами доповіді суспільна консолідація розуміється як “єдність соціуму на основі спільних цінностей і спільної мети” [1, с. 12]. Складовими такої стратегії пропонуються соціальне партнерство, демократія, культурна різноманітність плюралістичного суспільства та спільні зовнішньополітичні інтереси.

У пошуках теоретико-методологічних засад вищезазначеної стратегії натрапляєшь на роботу французького соціолога Жильбера Дюрана (1921-2012) “Антропологічні структури уявного”(1969). В цій автор пропонує доповнити традиційну дихотомію “об’єкт-суб'єкт”поняттям “траект”або феноменом, який “розташований”між об’єктом і предметом, між проектом (майбутнім) i минулим (історією). Таким траектом він назвав “імажінер”, що одночасно репрезентує “уявне”, “уяву”, “уявлення”. В контексті цієї теоретичної конструкції Ж. Дюран пропонує аналізувати архетипи колективного несвідомого за режимами діурну (день) і ноктюрну (ніч), а імажинер трактує як розгорнуту структуру уя- ви, яка живиться міфами колективного несвідомого [2, с. 1].

Рясним підгрунтям для нової теоретичної конструкції стає соціальна думка доби модерну, яка віддавала перевагу раціональному поясненню соціальної реальності та ролі соціальних суб'єктів у i розвитку. Так, французький соціолог Еміль Дюркгейм (1858-1917) пропонував розглядати суспільство як поза та над індивідуальну реальність, яка володіє щодо індивідів імперативною силою та не залежить від них. Німецький соціолог Макс Вебер (1864-1920) інтерпретував суб'єктність через поняття ідеальний тип та раціоналізація [3, с. 6-7].

Метою статті є висвітлення в контексті архетипового підходу феномену традиції як фактору консолідації суспільства в умовах соціального постмодерну.

Виклад основного матеріалу. Соціальні реформи, що випестовують нову якість українського суспільства мають складний системний характер. Вони охоплюють різні сфери суспільного життя - політику, економіку, культуру, структури соціальної організації та соціального контролю. При цьому якість радикальних інституційних перетворень визначальною мірою залежить від змін у людській психології - темпів демонтажу іi старих механізмів (зовнішнього - екстернального) соціального контролю та швидкості становлення (внутрішнього - інтернального) соціального контролю, який виступатиме гарантом сталості якісно нової суспільної системи під назвою Україна.

Водночас феномен соціальний контролю є одним із найбільш супе- 
речливих у сучасній системі соціологічної термінології. Найпоширенішим із них є розуміння соціального контролю як сукупності норм і цінностей суспільства, а також санкцій, які застосовуються з метою їх здійснення. Такої точки зору на механізм здійснення соціального контролю дотримувався, зокрема Е. Дюркгейм, який у своїй соціальній теорії відводив чільне місце контролю соціальних норм, наголошуючи, що їхня деформація призводить до аномії, тобто паралічу механізмів утворювання соціальних норм, та до кризових явищ у суспільстві, які пов'язані із демонтажем соціальної солідарності. При цьому суспільна воля у стані аномії є паралізованою [4, с. 64]. Тобто за цих соціально-історичних обставин можна спостерігати стан, коли інституційна сила ще $\epsilon$, індивідуальна воля є, а загальної сили волі єдиного суб'єкта, спрямованої на контроль за дотриманням соціальних норм, які складають основу механізму соціального контролю, вже немає. У цьому контексті М. Вебер у класичній праці “Протестантська етика та дух капіталізму"(1904) наголошував на важливості взаємовпливів між нормами соціального контролю та самоконтролем, зокрема у вигляді різноманітних форм релігійного аскетизму. Логічним розвитком цих ідей стає “імажинер”Ж. Дюрана, режим діурну якого під час минувшої епохи модерну стимулював дуальні, ієрархічні, патріархальні соціальні практики 3 їх домінантними форми зовнішнього (екстернального) соціального контролю за діяльністю соціальних суб'єктів. Відповідно соціальна уява (імажинер), що виникала у людей в режимі діурн, формувала передусім морально-етичні норми, покликані ззовні регулювати повсякденне суспільне життя. Встановлений, таким чином, в добу модерну механізм (звнішнього - екстернального) соціального контролю було закріплено відповідними соціальними інститутами, такими як інститути держави 3 їх інструментами примусу та засобами впливу на громадську думку.

Досить часто поняття соціального контролю ототожнюється із політичною владою. Наприклад, американський політолог Ганс Моргентау (1904-1980) під цим терміном розуміє контроль над свідомістю та діями інших [5, с. 140]. Саме цей метод соціального контролю застосовується від початку писемної історії. Так, він був основою політичного правління в стародавньому Сгипті, Месопотамії, де каста жерців таким чином реалізовувала сакральну владу. За часів пізнього середньовіччя, коли Реформація радикально змінила духовний світ пересічного західного європейця, i, на думку Нікколо Макіавеллі, відбулась інституційна диференціація релігійного життя та секуляризація політики. За цих умов індивідуальні навички здійснення ефективного соціального контролю набули для макіавеллівського Володаря особливої ваги.

Певного розвитку ідея соціального контролю набула в німецькій соціології. Зкорема, Фердинанд Тьоніс (1855-1936) генетично розрізняв два типи суспільств: традиційне, (Gemeinschaft) й індустріальне (Gesellschaft), яким були притаманні різні типи соціального контролю. 
Для першого, ще слабко структурованого суспільства, важливого значення мав традиційний авторитет і відповідно зовнішній контроль, а для індустріального, модерного суспільства - правова норма, яка спирається на внутрішній соціальний контроль. На думку Макса Вебера, традиційне панування грунтується на вірі у святість порядків, які існують здавна. Харизматичне панування засноване на відданості харизмі вождя. Легальне панування існує завдяки встановленим правилам. Найчистішим його типом є панування бюрократичне [6, с. 157].

Основи бюрократичного панування поставали у модерному суспільстві, яке заклало основи новітніх засобів творчого створення, накопичення та поширення інформації як важливого владного ресурсу. 3 розвитком сучасних комунікаційних технологій суттєвого значення набуває соціальна маніпуляція як метод управління, який полягає у розвитку прихованих впливів на масову свідомість і поведінку людей 3 метою примусити їх діяти (або проявляти пасивність) в інтересах певних соціальних сил [8, c. 286]. Найчастіше такий механізм соціального контролю реалізується через засоби масової інформації. Характеризуючи його, як один із проявів масової культури премєр-міністр Великобританії часів Другої світової війни Уінстон Черчілль (1874-1965) у своїх мемуарах наголошував, що після закінчення першої світової війни в умовах гострої соціальної кризи Великобританія була врятована від руйнівної соціальної революції громадською думкою, футболом та традиційними пивними пабами. Таким чином, соціальна уява та інструменти впливу на неї нейтралізували конфліктний соціальний потенціал і переключили свідомість людей на нову соціальну реальність, орієнтовану на консенсусні моделі суспільного дискурсу та прийняття важливих владних рішень.

Протягом XX ст. практика діяльності державних інституцій, що вдавалися до соціальних маніпуляцій, ставала все складнішою та поширеною. Соціотехніка державного управління дедалі більше орієнтувалася на безпосередній вплив на суспільство 3 метою прийняття та реалізації бажаних політико-управлінських рішень. Важливим інструментом такого впливу ставав соціальний контроль та різноманітні методи соціальної регуляції поведінки спільнот. Серед них правові норми, раціональна або ірраціональна аргументація чи навіть відверта маніпуляція і, нарешті, методи силового тиску. Весь цей арсенал спрямований на людину та громадську думку як головні об'єкти впливу засобів масової комунікації.

Оскільки те, що ми називаємо громадською думкою, як зазначав відомий британський політичний діяч Бенджамін Дізраелі (1804-1881), скоріше за все заслуговує назви суспільних емоцій - ця сфера є об'єктом постійних маніпуляцій, котрі стають універсальним механізмом ефективного соціального контролю за буттям інформаційного суспільства [7, с. 18]. Відповідно більш вузькою, навіть, можна сказати, спеціалізованою поставала уява соціального контролю в американській соціологічній думці. Здебільшого вона пов’я- 
зана 3 тлумаченнями організації контролю за різними втіленнями, насамперед, девіантної поведінки. Так, класик американської соціології Роберт Мертон (1923-2000), вважав, що американське суспільство інтенсивно породжує суттєве протиріччя між навіяними розвинутою споживацькою психологією бажаннями та колом законно досяжного, внаслідок чого відбувається послаблення норм та інститутів, які регулюють та дисциплінують поведінку людей, що врешті призводить до заперечення авторитету соціальних норм та до різноманітних форм девіантної поведінки [9, с. 282].

Отже, крім форм соціального контролю у вигляді певних владних механізмів, які діють на державному рівні та в структурах громадянського суспільства, а також контролю за девіантною поведінкою, не менш важливою категорією, що детермінує дві попередні є самоконтроль індивіду. Це поняття вдало передає термін соціальної психології - локус контролю, який полягає у фіксації ступеня та міри того, як особистість сприймає своє життя, тобто таким, що контролюється ㄲi власними зусиллями та діями, або контрольованим ззовні - випадком або анонімними зовнішніми силами [10, с. 74].

Вище названі форми соціального контролю завжди взаємодіють у складній системі та не можуть розглядатись окремо. Механізм соціального контролю функціонує саме завдяки складній взаємодії між відповідними інститутами, покликаними регулювати суспільні відносини та морально-етичні норми самоконтролю індивідів, чиї рішення суттєво впливають на інституційний соціальний контроль. Водночас будь-який функціональний вид соціального контролю завжди є відносним, адже дії історичних суб'єктів у певний час визначаються минулим, а також вони можуть детермінувати майбутнє, яке також може впливати на ці дії. Беручи ж до уваги, що природа соціальних норм модерного минулого є статичною, а соціальні норми постмодерна - динамічною, можна стверджувати, що соціальний контроль завжди залежить від хисткого балансу між соціальною статикою та динамікою.

У постмодерній ситуації, коли посилюється роль суб'єкта в соціально-історичному процесі, індивідуальне ставлення до суспільства стає ключовим фактором подальшого суспільного розвитку. Адже, як зазначав німецький філософ, засновник феноменологіï Едмунд Гуссерль (1859-1938), раніше всього мислимого є “Я”, яке предстає для суб’єкта-індивіда первісною інтенціональною базою його світу. За цих умов епоха постмодерну "розмиває”соціальні традиції. Все це відбувається в контексті нової смислотворчості. Одначе нові - динамічні норми, плинні стереотипи, всеосяжні комунікації і чутливий престиж набуваються сьогодні паралельно зі становленням людини як суб'єкта предметно-практичної діяльності. Ще на зорі людської історії Homo sapiens вирізнявся від стадних тварин 3 їх соціальними інстинктами наявністю нормативно-ціннісної системи, яка регулює індивідуальну поведінку. У цьому сенсі не мавпа створила людину своєю наполегливою працею, а навпаки - людина розумна піднялася над тваринним 
світом завдяки розвитку мовної комунікації. 3 виникненням особливої - інформаційно-знакової діяльності соціально-матеріальний світ ставав вже приреченим на "ідеалізацію магії Слова”. Від того часу між тваринним та соціальним світами з'явилась психологічна прірва. Важливим фактором антропосоціогенезу стали моральні заборони та етичні табу, роль яких у розвитку людини в праці “Табу і тотем”(1913) розкрив австрійський психоаналітик Зигмуд Фройд (1856-1939). Розвиваючи його ідеї швейцарець Карл-Густав Юнг концептуалізував зв'язок між соціальним і психічним (психологічним) в ідеї колективного несвідомого, що його становлять глибинні потоки людської історії.

Так, в епоху традиційного суспільства показовою була єдність біологічного і соціального в людині. Зокрема, давньогрецький мислитель Аристотель (384-322 до н. е.), підкреслюючи наявність у людині як частині природи рис тваринного (біологічного) та соціального (політичного), називав членів суспільства “політичними тваринами”. Натомість його вичитель Платон (427347 до н. е.) вважав, що індивіди об'єднуються в соціум аби забезпечити свої головні потреби. Найкраще зробити це може лише ідельне суспільство, оскільки соціальне життя є природною сутністю людини.

Певне заперечення біологічного в людині на користь соціального позначає релігійна традиція, яка різко протиставляє тілесне - гріховне духовному. В цій дихотомії біологічне забезпечує функціонування інстинктів в той час, як соціальне відповідає за культурні цінності та норми. Австрійський антрополог Конрад Лоренц (1903-1989), зокрема, вважає, що деякі вищі цінності, такі як співчуття, солідарність, альтруїзм прямо взаємодіють із інстинктами. Водночас соціальне дозволяє контролювати прояви біологічного. 3 іншого боку, культурні цінності не успадковуються біологічно, а є набутими соціально. Взагалі зв’язок між соціальним та сакральним є надзвичайно важливим. У цьому проявляється ієрархічність соціального світу. Соціальне виконує вітально важливі сакральні функції. По-перше, це стосується проблем зв’язку зі світом Абсолюту, духовності, функціонуванням механізмів психологічної компенсації, по-друге, соціальне та сакральне сприяють інтеграції, тобто об'єднанню членів певного соціуму навколо санкціонованого світогляду, морально-етичних норм, по-трете, сакралізація соціального в традиційному суспільстві легітимізувала механізми соціального контролю, формувала стереотипи масової поведінки, по-четверте, сакралізоване соціальне сприяє розв’язанню екзистенційних проблем через продукування нових сенсів суспільної діяльності на певних історичних етапах, нарешті, по-п'яте, традиційна легітимізація влади, як це довів М. Вебер, здійснюється через іiі сакралізацію.

Постійно відбувається інформаційно-енергетична взаємодія між соціумом та індивідом, тобто між “Ми”та “Я”. Відповідно вибудовуються комунікативні зв’язки між соцієтальною психікою, яка характеризує параметри соціуму як цілісності, та індивідуальною психікою 
певної особи. Отже, ми маємо всі підстави вважати суб'єктом лише ту складову частину соціуму, яка активно впливає на інші об'єкти поза собою. Наприклад, суб'єктами політики є великі соціальні групи зі своїми специфічними інтересами, які визначають сенс політичних дій. На певному етапі свого розвитку вони створюють власні політичні структури, покликані ефективно діяти в інтересах своїх груп.

Безпосередніми організатора політичних дій виступають індивіди, якщо вони визначають напрям, хід та зміст політичних процесів, тому важливу роль відіграє ще один суб'єкт - політичний лідер, як людина, котра має вирішальний вплив на членів певної соціальної групи. Лідер - суб'єкт, котрий здійснює організаційних та інтегруючий вплив. Як засвідчує багатий історичний досвід, діяльність лідера сприяє розкриттю творчого потенціалу малої або великої соціальної групи, іноді, навпаки перешкоджає цьому.

За типологією М. Вебера розрізняють наступні основні типи лідерства: традиційне, засноване на вірі в святість певного суб'єкта влади; раціональне, легальне або бюрократичне, яке базується на вірі в законність існуючого порядку та його доцільність; харизматичне лідерство, яке підтримується вірою в надзвичайні можливості, тобто фактично формується на основі культу особи. За стилем розрізняють авторитарне лідерство, яке передбачає одноосібний керівний вплив на основі механізму загрози застосування силових санкцій, та демократичне лідерство, котре дає можливість членам групи приймати участь у досягненні цілей та керувати їі діяльністю.

Найповніше роль суб'єкту в історії висвітлена в екзистенціальній філософській думці, різні напрямки якої об'єднує переконання в тому, що існування передує сутності. Так, французький екзистенціаліст Жан Поль Сартр (1905-1980) наголошував, що суб'єктивізм означає, з одного боку, що індивідуальний суб'єкт сам себе обирає, а 3 іншого боку що людина не може вийти за межі людської суб'єктивності. Вибираючи себе, я створюю загальне, розуміючи проект будь-якої іншої людини, до якої б епохи вона не належала. Ця абсолютність вибору не ліквідує відносність кожної епохи. Історичні обставини змінюються, людина може народитись рабом в язичницькому суспільстві, феодальним сеньйором, чи пролетарем. Не змінюється лише необхідність для неї бути в світі, бути у ньому за роботою, бути в ньому серед інших і бути в ньому смертною. Межі не об'єктивні та не суб'єктивні, скоріше вони мають об'єктивний та суб'єктивний боки.

Представник франкфуртської школи соціології Герберт Маркузе (1898-1979), наголошуючи на вадах індустріального суспільства, на конфлікті індивіда та суспільства, на суперечностях між свободою та екзистенцією, зазначав, що дійсність стала технологічною дійсністю, i суб'єкт тепер настільки тісно пов'язаний з об’єктом, що поняття об'єкта обов’язково включає в себе поняття суб'єкта. Сам суб'єкт є конститутивною часткою науково детермінованого об'єкта. Суб'єкт наукових методів і суб'єкт ділового життя - є 
вираженням однієї і тієї ж суб'єктивності - людини.

Вище наведенні думки характеризують, на наш погляд, лише початковий етап становлення постіндустріальної цивілізації, який людство переживає на межі XX-XXI століть і який є лише часткою їі великого життєвого циклу. Ми вже неодноразово писали, що суспільно-історичний розвиток можна дослідити як послідовне розгортання у часовому-просторовому континуумі універсальних епохальних циклів які є релевантними одиницями аналізу та прогнозу соціально-історичної дійсності [11].

Сучасні суспільства не просто відтворюють себе в історії, вони залучені до процесу створення мегасуспільства. Тому вирішальними соціальними відносинами сьогодні є не відносини з приводу власності, а відносини з приводу стратегії формування майбутнього. Ідеологія постмодерну заперечує статичні норми та процедури соціального життя, тотально критикує “великі сенси” та проекти. Втрачається віра в месіанські історичні перспективи. Постмодернізм позбавляє історію вектору майбутнього. Відповідно до концепту Ж. Дюрана постмодерн втягує суспільство у режим ноктюрну, тобто міфологічну уяву містичного, ірраціонального. Ящо провідними цінностями модерну були демократія, рівність і прогрес, то ліберали постмодерну, навпаки, стверджують рівнозначність будь-яких проміжків часу і пропонують залишити турботи про сенс і спрямованість соціального часу. Найбільш симптоматичним для постмодерну у тлумаченні соціального є повернення до концепцій, які віддають пріоритет біологічній складовій людини. Мова йде про расизм та соціал-дарвінізм, які виводять соціум на арену боротьби за існування, в якій перемагають лише найбільш адаптовані.

Треба підкреслити, що на умовній шкалі цінностей для панівного в Модерному часі суб'єкта “МИ” характерними є морально-етичні цінності в той час, як для суб'єкта “Я” постмодерної сучасності абсолютно природними є раціонально-прагматичні, можна навіть сказати, егоїстичні інтереси і цінності. Якщо для колективного суб'єкта категорія “Я”по суті $€$ еманацією “індивідуальних проявів народності”, то для суб'єкта-індивіда "МИ”вона є персоніфікацією суспільного [12, с. 67].

3 точки зору соціальної психології “Я-концепцію”для індивідуального та колективного суб’єктів представлено в таблиці наступним чином [13, с. 72]:

\begin{tabular}{|l|l|l|}
\hline Провідні цінності & Індивідуальний суб’єкт “Я” & \multicolumn{1}{|c|}{ Колективний суб’єкт “Ми” } \\
\hline Ідентифікація & Індивідуальні цілі & Суспільні цілі \\
\hline Пріоритет & $\begin{array}{l}\text { Особисті інтереси, права } \\
\text { та свободи }\end{array}$ & $\begin{array}{l}\text { Соціальні та групові інтереси } \\
\text { та солідарність }\end{array}$ \\
\hline Засудження & Конформізм & Егоїзм \\
\hline Гасло-стиль життя & “Будь вірним собі” & “Ніхто з нас не острів” \\
\hline Культура & Індивідуалістична & Колективна \\
\hline
\end{tabular}


Висновки і перспективи подальших досліджень. Таким чином, кожний тип соціального суб'єкта має власні риси політичної свідомості, яка різниться за п'ятьма основними ознаками.

По-перше, за характером та способом здійснення влади. В тоталітарному суспільстві - це загальний контроль та соціальним примус. В автократичному суспільстві - можуть виникати певні зони свободи, недоступні контролю. В перед демократичному суспільстві влада починає вести діалог з незалежними групами, які визріли за часів автократії в своєрідних анклавах суспільної свободи, але сама визначає результати цього діалогу. Нарешті, в демократичному суспільстві влада здійснюється на представницькій основі відповідно до законів.

По-друге, такою ознакою є ставлення людей до владного режиму. Для тоталітарної свідомості характерним є злиття з владою, для авторитарної свідомості - відчуження від влади, для перед демократичної свідомості - обмежений вплив на владу, для демократичної свідомості - вибір конкретних носіїв влади.

По-третє, важливим чинником є статус горизонтальних соціальних структур. Тоталітарний режим руйнує будь-які горизонтальні структури. Авторитарний режим допускає їхнє існування до того часу, поки вони не мають політичного характеру. Перед демократичний режим дозволяє будь-які організації, окрім тих, що претендують на владу. При цьому опозиція має такий же менталітет, що й влада. В демократичному суспільстві структура суспільних ор- ганізацій стає фундаментом політичної системи.

По-четверте, певне значення має ієрархія соціальних табу. В тоталітарному суспільстві дозволено те, що наказано владою, решта заборонено. В автократичному суспільстві право на життя має те, що не стосується політики. У перед демократичному суспільстві дозволено все, крім зміни влади. В демократичному суспільстві - дозволено все, що не заборонено законом.

Нарешті, п'ята ознака стосується політичних ідеалів. У тоталітарному суспільстві від влади вимагають всемогутності, а від людей - ентузіазму та скромності. В авторитарному суспільстві від влади вимагається компетентність, від людей - професіоналізм та вірність. У перед демократичному суспільстві від влади вимагають моральності, від людей активності, яка не обовязково поєднується з відповідальністю. У демократичному суспільстві від влади та громадян вимагається лише дотримання законів.

Чи можливо визначити універсальну формулу соціальної консолідації на основі традицій?

Такою загальною формулою, на наш погляд, може бути збереження консерватизму у принципах і традиціях, але допущення ліберального ставлення до суспільства. Таким чином гармонізується взаємодія традицій і соціальних інновацій. Зокрема, якщо третя хвиля індустріальної революції була можлива на основі національної консолідації та модерних традицій, то нині залишається відкритим залишається питання щодо соціальних механізмів забезпечення 
четвертої промислової революції. Такі технології як тримірний друк, біотехнології, нейротехнології, виробництво відтворювувальної енергії, блокчейн, штучний інтелект за визначенням є результатами транснаціональної індустріалізації.

Словом, ще попереду залишається селекція форм взаємодії соціальної інновації і традицій, аби національна держава не перетворилась на нову замкнену суспільну систему, яка функціонально не може реагувати на глобальні інноваційні тенденціï.

\section{СПИСОК ВИКОРИСТАНИХ} ДЖЕРЕЛ

1. Україна: шлях до консолідації суспільства: національна доповідь / Інститут політичних і етнонаціональних досліджень ім. І. Ф. Кураса НАН України ; Національна академія наук України, Секція суспільних і гуманітарних наук, Інститут політичних і етнонаціональних досліджень ім. І. Ф. Кураса НАН України. Київ, 2017. 336 с.

2. Дугин А. Г. Социология воображения. Введение в структурную социологию. Москва : Академический Проект; Трикста, 2010. 564 с. (Технологии социологии).

3. Щербина В. Субъектная составляющая теоретизирования как предмет рефлексии различных направлений социологии // Буття людини. Природа та соціум: соціально-філософські виміри. Вісник Харківського університету. 1998. № 5. С. 6-7.

4. Hermann Korte. Einführung in die Geschichte der Soziologie. München, 1992. $216 \mathrm{~s}$.

5. Політологія / За ред. О. І. Семківа. Львів : Світ, 1994. 592 с.
6. Вебер Макс. Соціологія. Загально-історичні аналізи. Політика / Пер. $з$ нім. О. Погорілого. Київ : Основи, 1998. $534 \mathrm{c}$.

7. Соціологія : короткий енцикл. слов. / уклад.: В. І. Волович, В. І. Тарасенко, М. В. Захарченко та ін. ; за заг. ред. В. І. Воловича. Київ, 1998. 736 с.

8. Кара-Мурза С. Манипуляция сознанием. Москва, 2000. 464 с.

9. Американская социология. Перспективы. Проблемы. Методы / Под общ. ред. Г. В. Осипова. Москва: Прогресс, 1972. 390 с.

10. Майерс Дэвид. Социальная психология. Санкт-Петербург: Питер, 1997. 688 с. (Серия “Мастера психологии”).

11. Афонін Е. А. Бандурка О. М., Мартинов А. Ю. Суспільний розвиток від Різдва Христового = Social Development AD / Укр. т-во сприяння соц. інноваціям, Атлантична Рада України. Від. інф.-бібл. забезпечення апарату Верховної Ради України ; пер. $з$ укр. В. В. Кухтіна. Київ : Парлам. вид-во, 2000. 312 с. (Серія відкрита досл. концепція; Вип. 1). Текст паралельно укр. та англ. мовами.

12. Казинцев А. И. Новые политические мифы. Опыт публицистического исследования. Москва : Молодая гвардия, 1990. 224 с. (Свободная трибуна).

13. Социальная психология: учеб. пособие для студентов и аспирантов психологических факультетов а также слушателей курсов психологических дисциплин на гуманитарных факультетах вузов. Санкт-Петербург ; Москва ; Харьков : Питер, 1998. 688 с.

\section{REFERENCES}

1. Ukraina: shliakh do konsolidatsii suspilstva: natsionalna dopovid [Ukraine: The Road to Social Consolidation: A National Report]. (2017). Kyiv: In- 
stytut politychnykh i etnonatsionalnykh doslidzhen im. I. F. Kurasa NAN Ukrainy ; Natsionalna akademiia nauk Ukrainy, Sektsiia suspilnykh i humanitarnykh nauk, Instytut politychnykh i etnonatsionalnykh doslidzhen im. I. F. Kurasa NAN Ukrainy [in Ukrainian].

2. Dugin, A. G. (2010). Sotsiologiya voobrazheniya. Vvedenie v strukturnuyu sotsiologiyu [Sociology of imagination. Introduction to structural sociology]. Moscow: Akademicheskiy Proekt; Triksta [in Russian].

3. Shcherbina, V. (1998). Subektnaya sostavlyayushchaya teoretizirovaniya kak predmet refleksii razlichnykh napravleniy sotsiologii [The subject component of theorizing as a subject of reflection of various areas of sociology]. Buttia liudyny. Pryroda ta sotsium: sotsialno-filosofski vymiry. Visnyk Kharkivskoho universytetu Being of a human. Nature and society: social and philosophical dimensions. Bulletin of Kharkiv University, 5, 6-7 [in Russian].

4. Korte, H. (1992). Einführung in die Geschichte der Soziologie. München [in German].

5. Semkiva, O. I. (Eds.). (1994). Politolohiia [Political Science]. Lviv: Svit [in Ukrainian].

6. Veber, M. (1998). Sotsiolohiia. Zahalno-istorychni analizy. Polityka [So- ciology. General historical analyzes. Politics]. (O. Pohorilyi, Trans). Kyiv: Osnovy [in Ukrainian].

7. Volovych, V. I., et. al. (Eds.). (1998). Sotsiolohiia: korotkyi entsykl. slov. [Sociology: a short encyclical dictionary]. Kyiv [in Ukrainian].

8. Kara-Murza, S. (2000). Manipulyatsiya soznaniem [Manipulation of consciousness]. Moscow [in Russian].

9. Osipov, G. V. (Eds.). (1972). Amerikanskaya sotsiologiya. Perspektivy. Problemy. Metody [American sociology. Prospects. Problems. Methods]. Moscow: Progress [in Russian].

10. Myers, D. (1997). Sotsialnaya psikhologiya [Social Psychology]. Saint Petersburg: Piter [in Russian].

11. Afonin, E. A. Bandurka, O. M., Martynov, A. Yu. (2000). Suspilnyi rozvytok vid Rizdva Khrystovoho = Social Development AD [Social Development since the Nativity of Christ $=$ Social Development AD]. Kyiv: Parlam. vyd-vo [in Ukrainian].

12. Kazintsev, A. I. (1990). Novye politicheskie mify. Opyt publitsisticheskogo issledovaniya [New political myths. The experience of journalistic research]. Moscow: Molodaya gvardiya [in Russian].

13. Sotsialnaya psikhologiya [Social psychology]. (1998). Saint Petersburg; Moscow; Kharkov: Piter [in Russian]. 